Vol. V No. 2, Maret 2021, hlm. 111 - 120

DOI: https://doi.org/10.36294/jmp.vxix.xxx

Available online www.jurnal.una.ac.id/indeks/jmp

\title{
PENGARUH PERHATIAN ORANG TUA DAN MOTIVASI BELAJAR SISWA TERHADAP HASIL BELAJAR MATEMATIKA SISWA SMP
}

\author{
Yanty Maria Rosmauli Marbun \\ Dosen Pendidikan Matematika FKIP Universitas HKBP Nommensen \\ Email : yantymarbun@uhn.ac.id
}

\begin{abstract}
This research aims to find out: (1) how the influence of parental support on the math learning achievement of students of SMP (2) how the influence of motivational learning on the math learning achievements of students of SMP (3) how the influence of parental support and learning motivation on the math learning achievement of students. This research is a regression study with the research population is all students grade VIII SMP N 1 Pematangsiantar School Year 2020/2021. The instrument used is a questionnaire or questionnaire using the Likert scale that has been tested validity and reliability. Analysis data uses simple regression formulas and multiple regressions. The results of the study at a significant level of 0.05 showed that: (1) There was a significant postif and significant influence on parental support for student math learning achievement with the acquisition of a positive regression coefficient of 0.225 (2) There was a significant influence between learning motivation to students' math learning achievement with a regression coefficient of 0.174 (3) With a positive value constant of 42,808
\end{abstract}

Keywords: Parental support, Learning motivation and Learning Achievement.

\begin{abstract}
Abstrak
Penelitian ini bertujuan untuk mengetahui: (1) bagaimana pengaruh perhatian orang tua terhadap hasil belajar matematika siswa SMP, (2) bagaimana pengaruh motivasi belajar terhadap hasil belajar matematika siswa SMP, 3) bagaimana pengaruh perhatian orang tua dan motivasi belajar terhadap hasil belajar matematika siswa. Penelitian ini merupakan penelitian regresi dengan populasi penelitian adalah seluruh siswa kelas VIII SMP Negeri 1 Pematangsiantar Tahun Ajaran 2020/2021. Instrumen yang digunakan adalah angket atau kuesioner dengan menggunakan skala Likert yang telah dilakukan uji validitas dan reliabilitas. Data analisis menggunakan rumus regresi sederhana dan regresi berganda. Hasil penelitian pada taraf signifikan 0,05 menunjukkan bahwa: (1) Terdapat pengaruh postif dan signifikan perhatian orang tua terhadap hasil belajar matematika siswa dengan perolehan koefisien regresi bernilai positif sebesar 0,225 (2) Terdapat pengaruh signifikan antara motivasi belajar terhadap hasil belajar matematika siswa dengan perolehan koefisien regresi sebesar 0,174 (3) Dengan perolehan konstanta bernilai positif sebesar 42,808
\end{abstract}

Kata Kunci: Perhatian orang tua, Motivasi belajar dan Hasil Belajar. 
Vol. V No. 2, Maret 2021, hlm. 111 - 120

DOI: https://doi.org/10.36294/jmp.vxix.xxx

Available online www.jurnal.una.ac.id/indeks/jmp

\section{PENDAHULUAN}

Matematika merupakan ilmu universal yang mempunyai peranan penting dalam kehidupan sehari-hari. Matematika juga merupakan ilmu dasar yang harus dikembangkan dan dipelajari oleh setiap siswa mulai dari jenjang sekolah dasar sampai ke perguruan tinggi karena dapat mengembangkan daya nalar kemampuan berfikir siswa tersebut (Suandito, 2017: 13). Dan matematika juga penting dipelajari untuk membekali peserta didik dengan kemampuan berfikir logis, analitis, sistematis, kritis dan kreatif dan kemampuan bekerja sama (Kamarullah, 2017:29). Mengingat pentingnya matematika dalam kehidupan sehari-hari, maka matematika perlu dipahami dan dikuasai oleh semua lapisan masyarakat tak terkecuali siswa sekolah sebagai generasi penerus.

Proses keberhasilan pembelajaran matematika dapat diukur dari keberhasilan siswa yang mengikuti kegiatan pembelajaran tersebut. Keberhasilan itu dapat dilihat dari tingkat pemahaman, penguasaan materi serta hasil belajar (Anim, A. (2018). Semakin tinggi pemahaman dan penguasaan serta hasil belajar maka semakin tinggi pula tingkat hasil keberhasilan pembelajarannya.

Hasil belajar dapat dicapai apabila proses belajar-mengajar dikatakan berhasil, dan ditunjukkan dengan hasil berupa skor atau nilai. Untuk mendapatkan nilai tersebut digunakan tes yang akan menunjukkan tinggi rendahnya hasil belajar siswa. Sehingga dapat dikatakan bahwa jika hasil belajar siswa tinggi maka siswa berhasil dalam pembelajarannya.

Oleh karena itu pada proses belajar mengajar siswa diharapkan memperoleh hasil belajar yang tinggi dengan cara memahami dan menguasai materi yang diajarkan sebagai evaluasi dalam proses belajar siswa dalam menguasai pelajaran matematika (Anim, A., \& Saragih, E. M. .2019). Namun hasil belajar tidak hanya dipegaruhi siswa itu sendiri, akan tetapi dari faktor lain yakni faktor internal dan faktor eksternal. Sebagaimana yang diungkapkan oleh Slameto (2010) yang menyatakan bahwa faktor eksternal, yaitu faktor yang datang dari luar diri siswa, seperti lingkungan keluarga, lingkungan sekolah, dan lingkungan masyarakat.

Dukungan orang tua sangat penting bagi siswa, karena siswa yang tinggal bersama orangtua sangat memerlukan perhatian dan bantuan dari orangtuanya. Orang tua adalah orang yang pertama dan utama yang bertanggung jawab terhadap kelangsungan hidup dan pendidikan anaknya, orangtua bertanggung jawab menyediakan dana dan dukungan sumber daya lainnya untuk kebutuhan pendidikan anak (Ningsih dkk., 2014:78). Dengan demikian diharapkan kepada orangtua untuk memberikan perhatian kepada anaknya guna meningkatkan prestasi belajar dengan cara mengontrol waktu belajar, 
Vol. V No. 2, Maret 2021, hlm. 111 - 120

DOI: https://doi.org/10.36294/jmp.vxix.xxx

Available online www.jurnal.una.ac.id/indeks/jmp

memantau perkembangan akademik, dan kepribadian yang mencakup sikap, moral dan tingkah laku anak, serta memberikan fasilitas belajar yang memadai untuk menunjang keefektifan belajar

Cara orang tua dalam memberikan perhatian terhadap anak memegang peranan penting dalam menanamkan dan membina anak. Pada dasarnya besar atau kecil pengaruh lingkungan dalam menumbuhkan motivasi belajar, tergantung kepada lingkungan itu sendiri. Dalam hal ini lingkungan yang mempengaruhi motivasi belajar terdiri dari: lingkungan keluarga, masyarakat, dan sekolah. Dari ketiga lingkungan tersebut, lingkungan keluarga merupakan suatu faktor yang sangat mempengaruhi siswa dalam menumbuhkan motivasi belajar, khususnya orang tua.

Belajar merupakan suatu kebutuhan yang dirasakan manusia sebagai suatu keharusan untuk dipenuhi sepanjang usia sejak lahir hingga akhir hayatnya. Belajar adalah suatu proses usaha untuk memperoleh perubahan tingkah laku yang menyangkut pengetahuan sebagai hasil pengalaman atau interaksi dengan lingkungan. Menurut Priansa (2017:88) bahwa "Pembelajaran pada hakekatnya adalah proses interaksi antara guru, peserta didik dan lingkungan yang ada disekitarnya, yang dalam proses interaksi tersebut terdapat upaya untuk meningkatkan kualitas diri peserta didik menjadi lebih baik dari sebelumnya”.
Hasil belajar merupakan hal yang terpenting dalam hasil proses pembelajaran karena merupakan alat ukur pencapaian kemampuan, pengetahuan dan pemahaman yang diperoleh. Hasil belajar matematika adalah kemampuan yang diperoleh peserta didik setelah melakukan proses pembelajaran berdasarkan hasil ujian dan tes. Dalam penelitian ini, hasil belajar matematika siswa diambil dari nilai raport.

Keluarga khususnya orangtua sebagai lembaga yang pertama kali dikenal oleh individu mempunyai peranan yang cukup penting terhadap lingkungan. Perhatian orangtua yang mencerminkan ketanggapan orangtua atas kebutuhan anak merupakan hal yang sangat penting bagi anak. Menurut Ellis, dkk (dalam Lestari, 2016: 59), "Perhatian orangtua sebagai interaksi yang dikembangkan oleh orangtua yang dicirikan oleh perawatan, kehangatan, persetujuan, dan berbagai perasaan positif orangtua terhadap anak. Perhatian orangtua adalah suatu pemberian orangtua yang dirasakan oleh individu sebagai bantuan baik secara fisik maupun verbal. Indikator perhatian orang tua yang digunakan peneliti dalam merumuskan angket adalah 1) perhatian melalui informasi orangtua, 2) Perhatian melalui penilaian orangtua, 3) perhatian instrumental orangtua, 4) perhatian melalui emosional orangtua.

Motivasi belajar adalah dorongan yang terjadi pada diri seseorang untuk melakukan kegiatan belajar sehingga 
Vol. V No. 2, Maret 2021, hlm. 111 - 120

DOI: https://doi.org/10.36294/jmp.vxix.xxx

Available online www.jurnal.una.ac.id/indeks/jmp

memiliki keinginan untuk belajar dan mencapai tujuan belajar yaitu memperoleh prestasi belajar yang tinggi. Motivasi mempengaruhi tingkat keberhasilan atau kegagalan belajar dan pada umumnya belajar tanpa motivasi akan sulit untuk berhasil. Oleh sebab itu, pembelajaran harus disesuaikan dengan kebutuhan, dorongan, motif, minat yang dimiliki oleh peserta didik. Penggunaan motivasi dalam mengajar bukan hanya melengkapi elemen pembelajaran, tetapi juga faktor yang menentukan pembelajaran yang efektif. Istirani (2019: 63) menyatakan ada beberapa fungsi motivasi dalam belajar, yaitu memberikan kekuatan pada daya belajar, memberi arah belajar yang jelas, mampu mengatasi rintangan, mewujudkan belajar mandiri, mendorong belajar secara terus-menerus, menumbuhkan keinginan untuk berprestasi dan meningkatan kualitas belajar.

Motivasi dalam belajar berfungsi sebagai pendorong kegiatan belajar dalam mencapai hasil belajar yang optimal. Motivasi memberikan dorongan dan arah dalam kegiatan yang dikerjakan agar sesuai dengan rumusan tujuannya. Banyak faktor yang mempengaruhi motivasi belajar siswa. Dengan demikian motivasi belajar pada diri siswa sangat dipengaruhi oleh adanya rangsangan dari luar dirinya serta kemauan yang muncul pada diri sendiri. Motivasi belajar yang datang dari luar dirinya akan memberikan pengaruh besar terhadap munculnya motivasi intrinsik pada diri siswa.
Sugiyono (2019), menyatakan bahwa kerangka berpikir merupakan sintesis tentang hubungan antar variabel yang disusun dari berbagai teori yang telah dideskripsikan. Untuk itu penelitian ini menentukan kerangka berpikir sebagai berikut: hasil belajar matematika adalah kemampuan yang diperoleh peserta didik setelah melakukan proses pembelajaran berdasarkan hasil ujian dan tes yang terlihat pada nilai. Pada penelitian ini prestasi belajar matematika siswa diambil dari nilai raport.

Secara operasional indikator perhatian orang tua meliputi:

1. Perhatian Informasional.

2. Perhatian Penilaian.

3. Perhatian Instrumental.

4. Perhatian Emosional.

Secara operasional indikator motivasi belajar meliputi: 1) Tekun menghadapi tugas, 2) Ulet menghadapi kesulitan, 3) Menunjukkan minat terhadap bermacam-macam masalah, 4) Lebih senang bekerja mandiri, 5) Tidak cepat bosan pada tugas-tugas yang rutin, 6) Dapat mempertahankan pendapatnya, 7) Tidak mudah melepaskan hal yang diyakini, Senang mencari dan memecahkan masalah soal-soal.

Dari rumusan masalah dapat dilihat ada dua variabel bebas yang dinyatakan dengan $\left(\mathrm{X}_{1}\right),\left(\mathrm{X}_{2}\right)$ dan satu variabel terikat dinyatakan dengan $(\mathrm{Y})$. Variabel bebas tersebut ialah perhatian orang tua $\left(\mathrm{X}_{1}\right)$ dan motivasi belajar siswa $\left(\mathrm{X}_{2}\right)$ dan variabel terikat ialah hasil belajar (Y). Akan dibuktikan apakah variabelvariabel berikut mempengaruhi, Variabel 
Vol. V No. 2, Maret 2021, hlm. 111 - 120

DOI: https://doi.org/10.36294/jmp.vxix.xxx

Available online www.jurnal.una.ac.id/indeks/jmp

$\left(\mathrm{X}_{1}\right)$ berpengaruh terhadap variabel $(\mathrm{Y})$ demikian juga variabel $\left(\mathrm{X}_{2}\right)$ berpengaruh terhadap variabel (Y) selanjutnya variabel $\left(\mathrm{X}_{1}\right)$ dan $\left(\mathrm{X}_{2}\right)$ berpengaruh terhadap variabel $(\mathrm{Y})$.

Berdasarkan rumusan masalah dan pengertian hipotesis yang diuraikan, maka yang menjadi hipotesis dalam penelitian ini adalah:

1. Terdapat pengaruh yang signifikan antara dukungan orang tua terhadap prestasi belajar SMP.

2. Terdapat pengaruh yang signifikan antara motivasi belajar siswa terhadap prestasi belajar matematika siswa SMP.

3. Terdapat pengaruh yang signifikan antara dukungan orang tua dan motivasi belajar siswa terhadap prestasi belajar matematika siswa SMP.

\section{METODE}

Jenis penelitian yang digunakan adalah jenis penelitian analisis regresi ganda dengan metode kuantitatif. Analisis regresi digunakan untuk memprediksikan seberapa jauh perubahan variabel dependen, bila nilai variabel independen dimanipulasi/ dirubah-ubah atau dinaik-turunkan Sugiyono (2019). Menurut Sugiyono (2019: 8), "Metode kuantitatif dapat diartikan sebagai metode penelitian yang berlandaskan pada filsafat positivisme, digunakan untuk meneliti pada populasi atau sampel tertentu, teknik pengambilan sampel pada umumnya dilakukan secara random, pengumpulan data menggunakan instrumen penelitian, analisis data bersifat kuantitatif/ statistik dengan tujuan untuk menguji hipotesis yang telah ditetapkan". Tujuan utama dalam penelitian ini adalah mengetahui pengaruh antara perhatian orang tua dan motivasi belajar siswa terhadap prestasi belajar matematika siswa kelas VIII SMP Negeri 1 Pematangsiantar.

Data prestasi belajar matematika didapat melalui dokumen nilai raport siswa tahun ajaran 2020/2021. Menurut Arikunto (2013: 274) menyatakan bahwa "Metode dokumentasi yaitu mencari data mengenai hal-hal atau variabel yang berupa catatan, transkip, buku, surat kabar, majalah, prasasti, notulen rapat, lengger, agenda dan sebagainya". Data kedua variabel ini diperoleh dengan menyebarkan angket, kemudian mengumpulkan data dari angket dan selanjutnya dilakukan pemeriksaan nilai data angket yang sudah diuji. Menurut Sugiyono (2019: 142), "Kuesioner (angket) merupakan teknik pengumpulan data yang dilakukan dengan cara memberi seperangkat pertanyaan atau pernyataan tertulis kepada responden untuk dijawabnya".

\section{HASIL DAN PEMBAHASAN}

Penelitian ini dilaksanakan di SMP Negeri 1 Pematangsiantar yang dilakukan secara online dalam jaringan melalui aplikasi google form. Data yang dikumpulkan pada penelitian ini adalah 
Vol. V No. 2, Maret 2021, hlm. 111 - 120

DOI: https://doi.org/10.36294/jmp.vxix.xxx

Available online www.jurnal.una.ac.id/indeks/jmp

data yang diperoleh dari kuesioner dukungan orang tua dan motivasi belajar.

Data tentang dukungan orang tua diperoleh dari pengisian angket oleh siswa kelas VIII SMP Negeri 1 pematangsiantar yang berjumlah 300 siswa, dan sampelnya berjumlah 66 siswa. Angket tersebut berbentuk skala Likert yang diisi oleh siswa dimana skala tersebut kemudian diberikan skor pada masing-masing butir yang tersedia. Data tersebut dapat dilihat dari tabel dibawah ini.
Table 1. data angket tentang dukungan orang tua

\begin{tabular}{cc}
\hline Statistik & $\begin{array}{c}\text { Skor perhatian } \\
\text { Orang Tua }\end{array}$ \\
\hline Sampel & 66 \\
\hline Skor Terendah & 40 \\
\hline Skor Tertinggi & 87 \\
\hline Rata - Rata & 62,07 \\
\hline Simpangan Baku & 10,9838 \\
\hline
\end{tabular}

Dari hasil penelitian maka data mengenai keterkaitan perhatian orang tua terhadap prestasi belajar matematika siswa disajikan pada tabel dibawah ini.

Tabel 2. Data Mengenai Keterkaitan Perhatian Orang Tua Terhadap Prestasi Belajar Matematika Siswa

\begin{tabular}{ccccc}
\hline Batas Kategori & Interval & Frekwensi & $\%$ & Ket \\
\hline$x<(\mu-\sigma)$ & $x<51,09$ & 14 & 21 & Rendah \\
\hline$(\mu-\sigma) \leq x<(\mu+\sigma)$ & $51,09 \leq x<73,05$ & 37 & 56 & Sedang \\
\hline$(\mu+\sigma) \leq x$ & $73,05<x$ & 15 & 23 & Tinggi \\
\hline Total & & 66 & 100 & \\
\hline
\end{tabular}

Berikut ini penyajian kategori dukungan orang tua dalam bentuk diagram lingkaran.

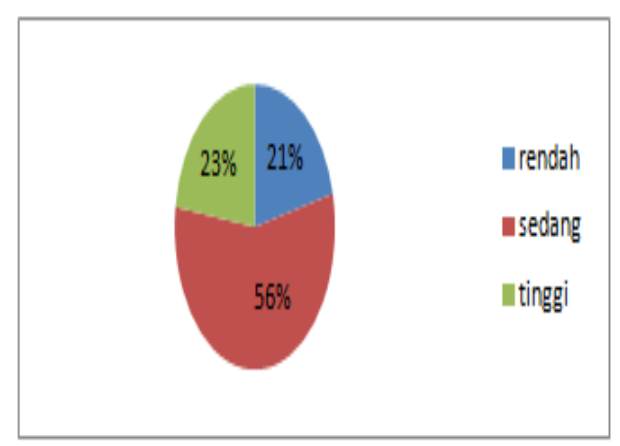

Diagram 1. Persentase Dukungan orang tua
Dari gambar tersebut, dapat disimpulkan bahwa kategori dukungan orang tua siswa SMP Negeri 1 Pematangsiantar pada seluruh subjek penelitian ini paling besar pada kategori sedang yaitu $56 \%$.

Data tentang motivasi belajar siswa diperoleh dari pengisian angket oleh siswa kelas VIII SMP Negeri 1 Pematangsiantar berjumlah 66 siswa. Angket tersebut diisi oleh siswa dengan skala yang diberikan kemudian diberikan skor pada masing-masing butir yang tersedia. Data tersebut dapat dilihat dari tabel dibawah ini. 


\section{MATEMATICS PAEDAGOGIC}

Vol. V No. 2, Maret 2021, hlm. 111 - 120

DOI: https://doi.org/10.36294/jmp.vxix.xxx

Available online www.jurnal.una.ac.id/indeks/jmp

\begin{tabular}{ll}
\hline Simpangan Baku $\quad 10.65$ \\
\hline
\end{tabular}

Table 3. Data tentang motivasi belajar siswa

\begin{tabular}{lc}
\hline \multicolumn{1}{c}{ Statistik } & $\begin{array}{c}\text { Skor } \\
\text { Motivasi } \\
\text { Belajar }\end{array}$ \\
\hline Sampel & 66 \\
\hline Skor Terendah & 47 \\
\hline Skor Tertinggi & 88 \\
\hline Rata - Rata & 66,10 \\
\hline
\end{tabular}

Dari hasil penelitian maka data mengenai keterkaitan motivasi belajar terhadap hasil belajar matematika siswa disajikan pada tabel dibawah ini.

Table 4. Keterkaitan Motivasi Belajar Terhadap Hasil Belajar Matematika Siswa

\begin{tabular}{clccc}
\hline Batas Kategori & \multicolumn{1}{c}{ Interval } & Frekuensi & Persentase & Ket \\
\hline$x<(\mu-\sigma)$ & $x<55,4708$ & 12 & $18 \%$ & Rendah \\
\hline $\begin{array}{c}(\mu-\sigma) \leq x<(\mu \\
+\sigma)\end{array}$ & $55,4708 \leq x$ & 43 & $65 \%$ & Sedang \\
& $<76,7715$ & & & \\
\hline$(\mu+\sigma) \leq x$ & $76,7715<x$ & 11 & $17 \%$ & Tinggi \\
\hline Total & & 66 & 100 & \\
\hline
\end{tabular}

Berikut ini penyajian kategori motivasi belajar dalam bentuk diagram lingkaran.

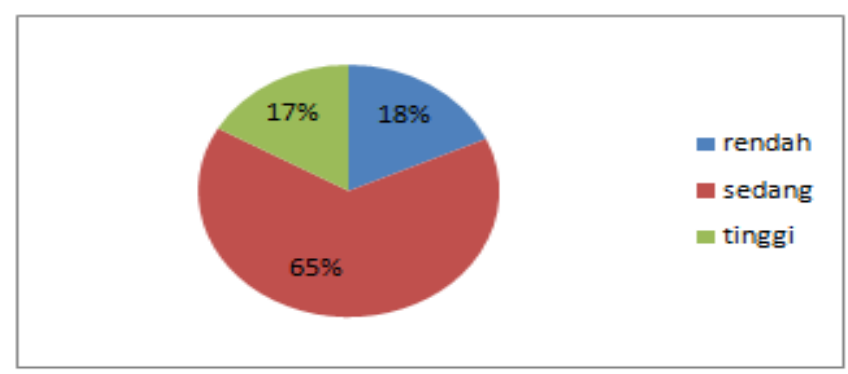

Diagram 1. Persentase Dukungan orang tua

Dari gambar tersebut, dapat disimpulkan bahwa motivasi belajar siswa pada seluruh subjek penelitian ini paling besar pada kategori sedang yaitu $65 \%$.

Berdasarkan data prestasi belajar matematika yang diperoleh melalui dokumentasi berupa nilai raport semester ganjil siswa kelas VIII SMP Negeri 1 Pematangsiantar. Berikut ini adalah tabel deskriptif data hasil belajar matematika siswa. 
Vol. V No. 2, Maret 2021, hlm. 111 - 120

DOI: https://doi.org/10.36294/jmp.vxix.xxx

Available online www.jurnal.una.ac.id/indeks/jmp

Table 5. Deskriptif Data Hasil Belajar Matematika Siswa Siswa

\begin{tabular}{lc}
\hline \multicolumn{1}{c}{ Statistik } & $\begin{array}{c}\text { Skor Hasil } \\
\text { Belajar }\end{array}$ \\
\hline Sampel & 66 \\
\hline Skor Terendah & 72 \\
\hline Skor Tertinggi & 89 \\
\hline Rata - Rata & 79.92 \\
\hline Simpangan Baku & 3,34269 \\
\hline \multicolumn{3}{c}{ Untuk mengkategorikan hasil } \\
belajar matematika yang diperoleh siswa
\end{tabular}

dapat dilihat dari kriteria ketuntasan minimum (KKM) sesuai dengan aturan yang diberikan sekolah. KKM yang telah ditetapkan oleh sekolah ialah 70 .

Pengujian hipotesis dalam penelitian ini dilakukan dengan menggunakan analisis regresi berganda dua prediktor. Dalam melakukan hipotesis ini, peneliti menggunakan bantuan SPSS 20. Penjelasan mengenai hasil pengujian hipotesis dalam penelitian ini sebagai berikut:

Table 6. Pengujian Hipotesis $H_{1}$ dengan $\mathrm{Y}$

\begin{tabular}{|c|c|c|c|c|c|c|}
\hline \multicolumn{7}{|c|}{ Coefficients $^{\mathrm{a}}$} \\
\hline \multirow{2}{*}{\multicolumn{2}{|c|}{ Model }} & \multicolumn{2}{|c|}{$\begin{array}{l}\text { Unstandardized } \\
\text { Coefficients }\end{array}$} & \multirow{2}{*}{$\begin{array}{l}\text { Standardized } \\
\text { Coefficients } \\
\text { Beta }\end{array}$} & \multirow[t]{2}{*}{$\mathrm{T}$} & \multirow[t]{2}{*}{ Sig. } \\
\hline & & $\mathrm{B}$ & Std Frror & & & \\
\hline \multirow{2}{*}{1} & (Constant) & 81,515 & 2,303 & & 35,394 &, 000 \\
\hline & Perhatian & .225 & ,036 &,- 085 & 2,394 & ,497 \\
\hline
\end{tabular}

Table 7. Pengujian Hipotesis $H_{2}$ dengan $\mathrm{Y}$

\begin{tabular}{|c|c|c|c|c|c|c|}
\hline \multicolumn{7}{|c|}{ Coefficients $^{\mathrm{a}}$} \\
\hline \multirow[t]{2}{*}{ Model } & & \multicolumn{2}{|c|}{$\begin{array}{l}\text { Unstandardized } \\
\text { Coefficients }\end{array}$} & \multirow{2}{*}{$\begin{array}{c}\text { Standardized } \\
\text { Coefficients }\end{array}$} & \multirow[t]{2}{*}{$\mathrm{T}$} & \multirow[t]{2}{*}{ Sig. } \\
\hline & & $\mathrm{B}$ & Std. Error & & & \\
\hline \multirow[b]{2}{*}{1} & (Constant) & 84,866 & 2,553 & & 33,241 & , 000 \\
\hline & $\begin{array}{l}\text { MOTIVAS } \\
\text { I }\end{array}$ & .174 & ,038 &,- 236 & 2,943 & ,056 \\
\hline
\end{tabular}

a. Dependent Variable: PRESTASI

Table 8. Pengujian Hipotesis $H_{1}$ dan $_{2}$ dengan $\mathrm{Y}$

\begin{tabular}{|c|c|c|c|c|c|}
\hline \multicolumn{6}{|c|}{ ANOVA $^{a}$} \\
\hline Model & $\begin{array}{l}\text { Sum of } \\
\text { Squares }\end{array}$ & Df & $\begin{array}{c}\text { Mean } \\
\text { Square }\end{array}$ & $\mathrm{F}$ & Sig. \\
\hline Regression & 42,808 & 2 & 21,404 & 1,870 &, $163^{b}$ \\
\hline
\end{tabular}


Vol. V No. 2, Maret 2021, hlm. 111 - 120

DOI: https://doi.org/10.36294/jmp.vxix.xxx

Available online www.jurnal.una.ac.id/indeks/jmp

\begin{tabular}{llll}
\hline Residual & 721,131 & 63 & 11,447 \\
\hline Total & 763,939 & 65 & \\
\hline a. Dependent Variable: HASIL \\
b. Predictors: (Constant), MOTIVASI, PERHATIAN \\
\hline
\end{tabular}

Pada table Pengujian Hipotesis $\boldsymbol{H}_{\mathbf{1}}$ dengan $\mathbf{Y}$, diketahui nilai Sig untuk pengaruh terhadap $\mathrm{Y}$ adalah sebesar $0,000<0,05$ dan nilai t hitung 2,394> 1,998, sehingga dapat disimpulkan bahwa $H_{1}$ diterima yang berarti terdapat pengaruh positif dan signifikan $X_{1}$ terhadap Y.

\section{Pada Pengujian Hipotesis $\boldsymbol{H}_{\mathbf{2}}$ dengan} Y, diketahui nilai Sig untuk pengaruh $X_{2}$ terhadap $Y$ adalah sebesar $0,000<0,05$ dan nilai t hitung lebih besar dari t tabel $2,943>1,998, \quad$ sehingga dapat disimpulkan bahwa $\mathrm{H}_{2}$ diterima yang berarti terdapat pengaruh positif dan signifikan $\mathrm{X}_{2}$ terhadap Y.

Pada Pengujian Hipotesis $H_{1}$ danH $_{2}$ dengan $\mathbf{Y}$, diketahui nilai Sig untuk pengaruh $X_{1}$ dan $X_{2}$ terhadap $\mathrm{Y}$ adalah sebesar $0,000<0,05$ dan nilai f hitung 2,9432,76 sehingga dapat disimpulkan bahwa $H_{3}$ diterima yang berarti terdapat pengaruh positif dan signifikan $X_{1}$ dan $X_{2}$ terhadap Y.

\section{DAFTAR RUJUKAN}

Anim, A., \& Saragih, E. M. (2019). Differences Of Students' Mathematical Communication Skills Through Contextual Teaching Learning With Problem Based Learning Model. Formatif:
Sehingga dapat disimpulkan bahwa terdapat pengaruh positif dan signifikan antara perhatian orang tua dan motivasi belajar terhadap hasil belajar matematika siswa.

\section{SIMPULAN}

Berdasarkan hasil penelitian tentang "Pengaruh Perhatian Orang Tua dan Motivasi belajar terhadap Hasil Belajar Matematika pada Siswa SMP maka penulis dapat menarik kesimpulan bahwa: Terdapat pengaruh yang positif dan antara Perhatian Orang Tua dan motivasi belajar terhadap Hasil Belajar Matematika Siswa SMP Pematangsiantar yang ditunjukkan oleh nilai signifikansi sebesar 0,000 dan $F_{\text {hitung }}>F_{\text {tabel. Nilai }}$ $F_{\text {hitung }}$ sebesar 1,870 dan $F_{\text {tabel }}$ sebesar 1,998 pada taraf signifikansi sebesar 0,05 (5\%). Hal ini menyebabkan Ho ditolak dan Ha diterima sehingga perhatian orang tua dan motivasi belajar berpengaruh terhadap hasil belajar matematika siswa SMP Negeri 1 Pematangsiantar.

\section{Jurnal Ilmiah Pendidikan MIPA, 9(1).}

Anim, A. (2018). Upaya Meningkatan Hasil Belajar Matematika Melalui Penerapan Strategi inside-outside Circle (IOC) di kelas VIII MTs 
Vol. V No. 2, Maret 2021, hlm. 111 - 120

DOI: https://doi.org/10.36294/jmp.vxix.Xxx

Available online www.jurnal.una.ac.id/indeks/jmp

Swasta Al-Istiqomah Kec. Tanah jawa. JURNAL DIALOG, 6(1), 534-545

Arikunto, Suharsimi. 2013. Prosedur Penelitian. Jakarta: Rineka Cipta

Istirani \& Pulungan, Intan. 2019. Ensiklopedi Pendidikan.Jilid 1. Medan: Larispa

Kamarullah, 2017. "Pendidikan Matematika Di Sekolah Kita". Jurnal Pendidikan Dan Pembelajaran Matematika. Vol.1(1): hal. 21-32.

Lestari, Sri. 2016. Psikologi KeluargaPenanaman Nilai dan Penanganan Konflikdalam keluarga. Jakarta: Kencana Prenada Media Grup.

Ningsih, S, H., Sulistyaningsih, Wiwik \& Hardjo, Suryani. 2014.
"Hubungan Antara Kebiasaan Belajar Dan Dukungan Orangtua Dengan Prestasi Belajar". Vol 6(2).

Priansa, Donni Juni. 2017. Pengembangan Strategi \& Model Pembelajaran. Bandung: Pustaka Setia

Slameto. 2010. Belajar dan Faktorfaktor Yang Mepengaruhinya. Jakarta: RinekaCipta.

Suandito, B. 2017. Bukti Informal dalam Pembelajaran Matematika. Jurnal Pendidikan Matematika. Vol8, No, Hal 13-24.

Sugiyono. 2011. Statistika Untuk Penelitian. Bandung. Alfabeta

Sugiyono.2019. Metode Penelitian kuantitatif, kualitatif dan $R \& D$. Bandung: Alfabet 